$$
\begin{gathered}
\text { 지충이 에탄올 추출물의 } \alpha \text {-amylase 저해활성 } \\
\text { 이소정·송유진·김꽃봉우리·이청조·정지연·곽지희 } \\
\text { 최문경·김민지·김태완 }{ }^{1} \text { 안동현* } \\
\text { 부경대학교 식품공학과 / 식품연구소, }{ }^{1} \text { 안동대학교 식맹명공학과 }
\end{gathered}
$$

\title{
Inhibitory Effects of Sargassum thunbergii Ethanol Extract against $\alpha$-amylase
}

\author{
So-Jeong Lee, Eu-Jin Song, Koth-Bong-Woo-Ri Kim, Chung-Jo Lee, \\ Ji-Yeon Jung, Ji-Hee Kwak, Moon-Kyoung Choi, Min-Ji Kim, \\ Tae-Wan Kim ${ }^{1}$ and Dong-Hyun Ahn* \\ Department of Food Science and Technology / Institute of Food Science, \\ Pukyong National University, Busan 608-737, Korea \\ ${ }^{1}$ Department of Food Science \& Biotechnology, Andong National University, \\ Gyeongbuk 760-740, Korea
}

This study was performed to investigate the inhibitory activity of Sargassum thunbergii (ST) against a-amylase and elucidate the availability of ST extract as a functional food agent. To test the inhibitory activity of ST against a-amylase, porcine pancreatic a-amylase and potato starch were used as substrates. It was revealed that ST crude ethanol extracts have high a-amylase inhibitory activity. Subsequently, ST crude ethanol extract was separated into five partition layers by solvent extraction: $n$-hexane, chloroform, ethyl acetate, butanol, and water. Chloroform and $n$-hexane fractions showed higher inhibitory activities than did acarbose (positive control). To confirm the changes in enzyme inhibitory activity by physical treatments, ST crude ethanol extract was subjected to heat, $\mathrm{pH}$, and $\gamma$-irradiation treatments. In all heat treatments with the exception of one $\left(121^{\circ} \mathrm{C}, 15 \mathrm{~min}\right)$, the inhibitory activity was increased compared with the untreated group. With regard to $\mathrm{pH}$ stability, ST extract showed no significant changes at $\mathrm{pH} 4-6$, but somewhat decreased inhibitory activity was revealed at $\mathrm{pH} \mathrm{2,8}$, and 10 . On the other hand, ST ethanol extract was stable under $\gamma$-irradiation under all conditions (3-20 kGy). In summary, ST ethanol extract can be used in the food industry as a natural a-amylase inhibitor.

Key words: Sargassum thunbergii, ethanol extracts, $\alpha$-amylase inhibitor

\section{서 론}

효소 저해물질은 효소 활성부위의 구조나 촉매반응기구의 해석에 이용되거나, 복잡한 생리기능에 있어서 효소의 역할 및 질병에 관여하는 효소의 해명에 중요한 역할을 해왔다 (Moon et al., 1998). 이와 함께 특정 효소의 기능을 억제하여 질병을 치료하는 치료제로서 임상적으로도 매우 중요한 물질 이기도 하다 (Puls and Neup, 1973). a-Amylase는 탄수화물의 a-D-(1,4)-glucan 결합을 분해하는 효소로 식품의 탄수화물은 $a$-amylase에 의해 분해되어 체내에 흡수되기 쉬운 형태의 당으로 변해 생명유지를 위한 탄소원 및 에너지원으로 이용된 다. 이를 통해 $a$-amylase와 같은 전분분해 효소의 대사적 중요성을 이해 할 수 있다 (Kim et al., 2010). 그러나 종종 전분 분해효소들의 과잉반응은 당의 급격한 생성과 이에 따른 유기산 생성을 야기하여 당뇨, 비만 및 산독증 (acidosis) 등의 질병을 유발하게 된다 (Gao and Kawabata, 2005; Ha et al., 1985; Kim, 1997). 따라서 이러한 질병의 예방과 치료를 위해 a-amylase 같은 전분분해 효소의 활성을 조절할 필요가 있다.

\footnotetext{
*Corresponding author: dhahn@pknu.ac.kr
}

특히, a-amylase 저해제는 당뇨, 비만 및 산독증 등의 예방과 치료제로서 임상적 의의가 큰 효소저해제이다 (Baht et al., 2008; McLaughlin et al., 2009). 현재 a-amylase 저해제로서 의약품으로 시판중인 acarbose는 방선균인 Actinoplanes sp.의 발효에 의해 생산되는 것으로 췌장과 침샘의 $\mathrm{a}$-amylase와 소장의 brush border에 존재하는 a-glucosidase의 활성을 저해 하여 탄수화물 소화 및 흡수를 지연시킨다 (Mahmud et al., 1999; Choi et al., 2008a). 그러나 acarbose는 뛰어난 효능에도 불구하고 복부팽만감, 복명, 설사 등의 부작용이 있는 것으로 알려지면서 안전성에 있어 문제가 되고 있다 (Kageyama et al., 1997). 따라서 최근에는 식이가 가능하며 부작용이 적은 천연 식물체로부터 a-amylase 저해제를 개발하기 위한 연구 가 활발히 이루어지고 있다. a-Amylase 저해물질은 Chrzaszcz and Janicki (1933)에 의해 처음으로 보고된 이래로 많은 식물 체에 함유되어 있는 것으로 알려졌는데, 특히 두류(Mulimani and Rudrappa, 1994)와 밀 (Granum, 1978)에서 많은 연구가 수행되어 왔다. 그리고 최근에는 말채나무 (Lim et al., 2005), 제비꽃 (Lee et al., 2008), 사방오리나무 (Choi et al., 2008b) 및 녹차 (Hara and Honda, 1990) 등의 식물체나 생약제 등에 
a-amylase 저해물질이 함유되어 있음이 밝혀졌다. 이처럼 천연물 유래 $a$-amylase 저해물질에 대한 연구는 밀, 두류, 생약재 등의 육상식물에서 유래한 물질이 주를 이루고 있는 반면, 해양식물에 대한 효소저해제 연구는 육상식물에 비해 미흡한 실정이다. 지금까지 알려진 해조류 유래의 a-amylase 저해제는 패, 감태 및 대황 등에서 분리된 물질들이 보고 (Heo et al., 2009; Lee et al., 2009a; Cho et al., 2008)되고 있을 뿐, 광대한 자원에 비해 연구는 미흡한 수준이다. 한편, 지충이 (Sargassum thunbergii)는 갈조식물 (Phaeophyta) 모자반과 (Sargassaceae)에 속하며 우리나라 전 연안에서 흔히 볼 수 있는 해조류이다. 어린식물은 사료로 사용되고 있으나 크게 이용되지 못하고 있는 자원으로 항산화 (Choi et al., 2006a: Yang et al., 2005), 항염증 (Kang et al., 2008), 항균 (Lee et al., 2009b) 및 항암 (Ryu et al., 1989)등의 생리활성에 대한 연구만 일부 보고되고 있을 뿐 효소저해제에 대한 연구는 보고되지 않고 있다.

이에 본 연구에서는 탄수화물 소화효소인 a-amylase에 대 한 지충이 추출물의 저해 효과를 측정하고, 열, $\mathrm{pH}$ 및 감마선 조사에의 안전성을 측정하여 기능성 식품 소재로서 산업적 이용 가능성을 알아보았다.

\section{재료 및 방법}

실험재료

본 실험에 사용된 지충이 (Sargassum thunbergii)는 부산 기장에서 채취한 것으로 담수로 깨끗이 수세하여 이물질을 제거하고 동결건조하여 분쇄기로 (Deasung atron, Seoul, Korea) 분쇄한 후 $-20^{\circ} \mathrm{C}$ 에서 보관하면서 실험에 사용하였다.

\section{추출}

물 및 에탄올 추출

지충이 분말에 10 배량의 에탄올 또는 물을 가하여 실온에서 shaker (Dongwon Science Co., Busan, Korea)로 24시간 추출한 후, $3000 \mathrm{rpm}$ 에서 10 분간 원심분리 (UNION 32R, Hanil Co., Incheon, Korea)하였다. 상층액은 취하고 잔사에 다시 10 배량 의 용매를 가하여 2회 반복 추출하였다. 상층액을 여과지 (Advantec 5A, Toyo roshi kaisha, Tokyo, Japan)로 여과하여 $37^{\circ} \mathrm{C}$ 에서 rotary evaporator (RE200, Yamato Co., Tokyo, Japan) 로 농축시킨 뒤 $-20^{\circ} \mathrm{C}$ 에서 보관하면서 사용하였다.

에탄올 추출물의 용매분획

지충이 에탄올 추출물을 극성을 높여가며 용매별 분획물 을 얻었다. 즉, 지충이 에탄올 추출물을 10 배량의 증류수에 현탁한 후, 동량의 $n$-hexane을 가하여 $180 \mathrm{rpm}$ 에서 1시간동 안 shaker (Dongwon Science Co., Busan, Korea)에서 교반하였 다. 이를 정치시켜 상층액을 취하고, 여과, 감압 농축 (RE200, Yamato Co., Tokyo, Japan)하여 $n$-hexane층을 얻었다. 계속해 서 같은 방법으로 수층을 chloroform, ethyl acetate, butanol로 용매분획한 다음 농축하여 각각 분획물을 얻었으며, 최종적 으로 물 분획물을 얻었다. 분획물의 수율은 다음과 같이 계산
하여 표기하였다.

수율 $(\%)=$ 용매분획물 건조 중량 $(\mathrm{g}) /$ 에탄올 추출물 건조 중량 $(\mathrm{g}) \times 100$

\section{총 페놀화합물 함량}

총 페놀화합물 함량은 Folin-Denis법 (Swain and Hillis, 1959) 을 변형하여 측정하였다. 즉 시료 $0.5 \mathrm{~mL}$ 과 Folin-ciocalteu's 용액 $0.5 \mathrm{~mL}$ 를 혼합하여 실온에 3 분간 정치시켰다. 여기에 무수 탄산나트륨 포화용액 $1 \mathrm{~mL}$ 을 첨가하고 초순수로 반응용 액이 $10 \mathrm{~mL}$ 이 되게 정용하였다. 상온에서 1시간 방치시킨 후, UV/visible spectrophotometer로 $765 \mathrm{~nm}$ 에서 흡광도를 측정 하였다. 표준물질로 gallic acid을 사용하여 검량곡선을 작성하 여 시료의 총 페놀화합물 함량을 구하였다.

\section{$a$-Amylase 저해활성 측정}

Porcine pancreatic amylase (EC 3.2.1.1, type VI, Sigma, MO, USA)에 대한 저해활성은 potato starch (typeIV, Sigma, MO, USA)를 기질로 하여 Ali 등 (Ali et al., 2006)의 방법을 변형하 여 측정하였다. 농도별로 희석한 시료 $40 \mu \mathrm{L}$ 와 $16 \mathrm{unit} / \mathrm{mL}$ 의 $\mathrm{a}$-amylase $200 \mu \mathrm{L}$ 를 혼합하여 $25^{\circ} \mathrm{C}$ 에서 5 분간 반응시킨 후, $0.5 \% \operatorname{starch} 400 \mu \mathrm{L}$ 를 혼합하여 다시 3 분간 반응하였다. 이 반응액을 $200 \mu \mathrm{L}$ 취하여 $96 \mathrm{mM} \mathrm{DNS} \mathrm{(3,} \mathrm{5-dinitrosalicylic}$ acid, potassuim sodium tartrate in $2 \mathrm{M} \mathrm{NaOH}$ ) 발색시약 100 $\mu \mathrm{L}$ 와 혼합시킨 후 $85^{\circ} \mathrm{C}$ 에서 15 분간 반응시켰다. 초순수 900 $\mu \mathrm{L}$ 를 첨가하여 효소 반응을 중지시키고 $540 \mathrm{~nm}$ 에서 흡광도 를 측정하였다. 항당뇨 치료제로 사용되고 있는 a-amylase inhibitor인 acarbose (Sigma, MO, USA)를 positive control로 사용하였으며 시료의 농도는 추출물의 건조중량을 기준으로 하여 나타내었다.

저해율 $(\%)=100-[($ 시료를 첨가한 흡광도/시료를 첨가하지 않은 흡광도 $) \times 100]$

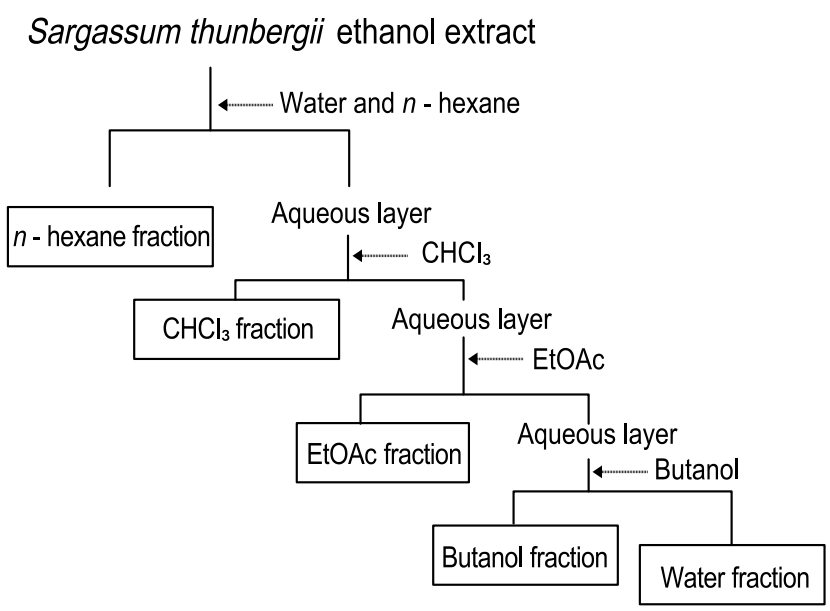

Fig. 1. The procedure to obtain the solvent fraction from ethanol extracts of Sargassum thunbergii. 
감태 에탄올 추출물의 $a$-Amylase 저해 특성

열 및 $\mathrm{pH}$ 처리

열처리는 추출물의 농도를 $5 \mathrm{mg} / \mathrm{mL}$ 로 하여 $60^{\circ} \mathrm{C}$ 에서 10 , 30 및 60 분, $80^{\circ} \mathrm{C}$ 와 $100^{\circ} \mathrm{C}$ 에서 각각 10 및 20 분, $121^{\circ} \mathrm{C}$ 에서 15 분 처리하였다. 이를 급냉시킨 후 실험에 사용하였다. $\mathrm{pH}$ 처리는 추출물의 농도를 $10 \mathrm{mg} / \mathrm{mL}$ 로 하여 $1 \mathrm{~N} \mathrm{NaOH}$ 와 1 $\mathrm{N} \mathrm{HCl}$ 을 가하여 $\mathrm{pH} 2,4,6,8$ 및 10 으로 처리하고 24 시간 실온에서 방치시킨 후 본래의 $\mathrm{pH}$ 로 중화시켜 이를 $5 \mathrm{mg} / \mathrm{mL}$ 농도로 희석하여 실험에 사용하였다.

감마선조사

한국원자력연구원 방사선과학연구소에 있는 감마선 조사 시설 (Point source AECL, IR-79, MDS Nordion International Co., Ltd., Ottawa, ON. Canada)을 이용하여 선원 10 만 Ci, Co-60 을 실온에서 시간당 일정 선량률로 분말 또는 추출물에 각각 3,7 및 $20 \mathrm{kGy}$ 의 총 흡수선량을 얻도록 조사하였다. 감마선 조사한 시료는 $4^{\circ} \mathrm{C}$ 에서 보관하면서 실험에 사용하였다.

통계처리

실험결과에 대한 통계처리는 SAS program(Statistical analytical system V8.2, SAS Institute Inc., Cary, NC, USA)을 이용하여 분산분석을 하였으며 조사 항목들 간의 유의성 검정 은 $P<0.05$ 수준에서 Duncan의 다중검정법으로 실시하였다.

\section{결과 및 고찰}

지충이 추출물의 $a$-amylase 저해활성

지충이 에탄올 및 물 추출물을 $5,2.5$ 및 $1 \mathrm{mg} / \mathrm{mL}$ 농도에서 a-amylase 저해활성을 알아본 결과 (Table 1), 에탄올 추출물 에서 각각 69,59 및 $35 \%$ 의 높은 저해활성을 보인 반면, 물 추출물에서는 저해활성이 나타나지 않았다. 일반적으로 물 추출물에는 친수성 물질들이 추출되며, 에탄올 추출물에는 소수성 물질과 일부의 친수성 물질이 모두 추출된다 (Kim et al., 2008). 따라서 지충이 에탄올 추출물에 a-amylase 저해 활성이 뛰어난 소수성 물질이 다량 추출된 것으로 사료된다. 이러한 결과는 말채나무의 에탄올 추출물이 물 추출물 보다

Table 1. a-Amylase inhibitory activity and of ethanol and water extracts Sargassum thunbergii

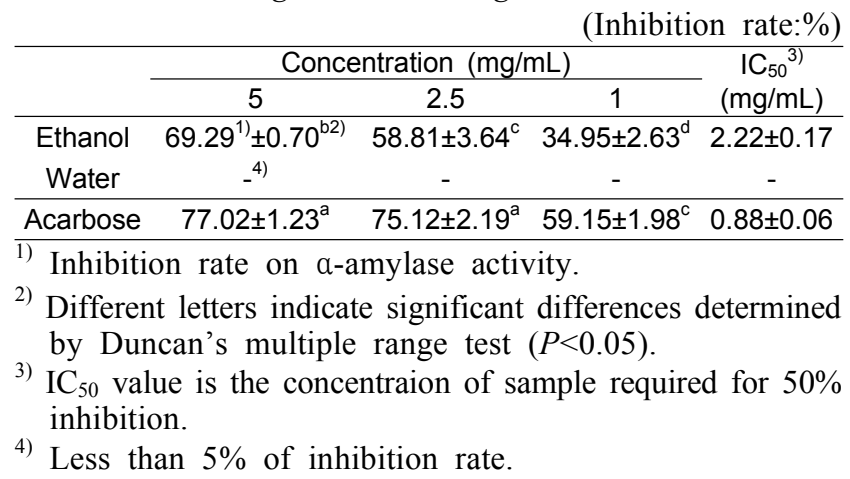

높은 a-amylase 저해활성을 보인 $\operatorname{Lim}$ 등 (2005)의 연구와 유사한 결과였다. 본 연구에서 나타난 지충이 에탄올 추출물 의 a-amylase 저해활성의 $\mathrm{IC}_{50}$ 값은 $2.22 \mathrm{mg} / \mathrm{mL}$ 로 positive control로 사용한 acarbose $(0.88 \mathrm{mg} / \mathrm{mL})$ 에 비해 2.5 배 정도 높은 값이었다. 그러나 $\mathrm{Lim}$ 등 (2005)이 보고한 말채나무 에탄 올 추출물의 a-amylase 저해활성의 $\mathrm{IC}_{50}$ 값이 acarbose의 약 24 배였고, Choi 등 (2008b)이 보고한 사방오리나무 메탄올 추출물의 a-amylase 저해활성의 $\mathrm{IC}_{50}$ 값이 약 3.72 배인 결과와 비교 할 때 이들 보다 효과적임을 알 수 있었다. 지금까지 알려진 해조류 유래의 a-amylase 저해 물질에는 패로부터 정제된 diphlorethohydroxycarmalol (Heo et al., 2009), 감태로 부터 분리된 phloroglucinal 유도체 (Lee et al., 2009a), 곰피 유래의 polyphenols (Iwai, 2008) 등의 페놀성 물질이 보고되고 있다. Bitou 등 (1999)은 해조류에 들어있는 이러한 페놀화합 물이 효소나 단백질과 수소결합과 소수성 상호작용을 통해 강한 복합체를 만들어 침전함으로써 효소의 활성을 저해한다 고 보고하였다. 이에 본 연구에 사용한 지충이 에탄올의 총페 놀화합물 함량을 측정한 결과, 에탄올 추출물 $1 \mathrm{~g}$ 에 $107 \mathrm{mg}$ 의 페놀화합물이 함유되어 있는 것을 확인하였으며, 이러한 결과 로 지충이 에탄올 추출물에 들어있는 다량의 페놀화합물이 a-amylase 저해에 관여하여 높은 저해 활성을 나타낸 것으로 사료된다.

Table 2. Effect of heat on a-amylase inhibitory activity of ethanol extract from Sargassum thunbergii

\begin{tabular}{ccl}
$\begin{array}{c}\text { Temperature } \\
\left({ }^{\circ} \mathrm{C}\right)\end{array}$ & $\begin{array}{c}\text { Time } \\
(\mathrm{min})\end{array}$ & $\begin{array}{c}\text { Inhibition rate } \\
(\%)\end{array}$ \\
\hline 60 & 10 & $76.46 \pm 0.93^{\mathrm{ab} 1)}$ \\
& 30 & $75.97 \pm 0.09^{\mathrm{ab}}$ \\
& 60 & $75.98 \pm 0.16^{\mathrm{ab}}$ \\
\hline 80 & 10 & $78.42 \pm 2.51^{\mathrm{a}}$ \\
& 20 & $78.10 \pm 1.25^{\mathrm{ab}}$ \\
\hline 100 & 10 & $76.62 \pm 1.71^{\mathrm{ab}}$ \\
& 20 & $73.46 \pm 0.72^{\mathrm{b}}$ \\
\hline 121 & 15 & $61.32 \pm 0.61^{\mathrm{d}}$ \\
\hline Control & & $66.31 \pm 0.82^{\mathrm{c}}$ \\
\hline
\end{tabular}

1) Different letters indicate significant differences determined by Duncan's multiple range test $(P<0.05)$.

열 처리에 의한 $a-a m y l a s e$ 저해활성 변화

높은 $a$-amylase 저해활성을 보인 지충이 에탄올 추출물의 열안정성을 측정하기 위해, $60^{\circ} \mathrm{C}$ 에서 10 분, 30 분 및 60 분, $80^{\circ} \mathrm{C}$ 와 $100^{\circ} \mathrm{C}$ 에서 각각 10 분 및 20 분, $121^{\circ} \mathrm{C}$ 에서 15 분간 열처리하 고 급냉한 후, $a$-amylase 저해활성을 측정하였다 (Table 2). 그 결과, $121^{\circ} \mathrm{C}, 15$ 분 처리구가 무처리구에 비해 유의적으로 낮은 저해활성을 보였다. 그러나 $121^{\circ} \mathrm{C}, 15$ 분 처리구를 제외한 모든 처리구의 a-amylase 저해활성이 무처리구에 비해 유의 적으로 증가하였다. $100^{\circ} \mathrm{C}$ 에서 열처리 후 $\alpha$-amylase 저해활 성을 측정한 다른 연구들을 보면, $\operatorname{Lim}$ 등 (2005)이 보고한 말채나무의 추출물의 a-amylase 저해활성은 열처리에 안정 하였으나, Mulimani and Rudrappa (1994)가 보고한 병아리 
콩의 경우 초기 활성에 비해 $37 \%$ 감소한 활성을 보여 본 연구 와 다른 결과를 나타내었다. Choi 등 (2006b)에 따르면 식물체 를 열처리하였을 때 결합형의 폴리페놀 성분이 유리형으로 전환되어 활성이 증가한다고 보고하였다. 따라서 열처리에 따른 지충이 추출물의 활성 증가는 유리형의 페놀화합물의 증가에 기인한 것으로 사료된다. 따라서 지충이 에탄올 추출 물은 열에 의해 활성이 증가하기 때문에 고열처리를 하는 식품에도 효과적으로 이용할 수 있을 것으로 사료된다.

Table 3. Effect of $\mathrm{pH}$ on a-amylase inhibitory activity of ethanol extract from Sargassum thunbergii

\begin{tabular}{cc}
\hline $\mathrm{pH}$ & Inhibition rate $(\%)$ \\
\hline 2 & $38.27 \pm 0.19^{\mathrm{c} 1)}$ \\
4 & $71.41 \pm 1.38^{\mathrm{a}}$ \\
6 & $70.36 \pm 1.06^{\mathrm{a}}$ \\
8 & $54.48 \pm 0.85^{\mathrm{b}}$ \\
10 & $38.14 \pm 0.39^{\mathrm{c}}$ \\
\hline Control $(4.8)$ & $70.76 \pm 1.36^{\mathrm{a}}$ \\
\hline
\end{tabular}

${ }^{1)}$ Different letters indicate significant differences determined by Duncan's multiple range test $(P<0.05)$.

$\mathrm{pH}$ 처리에 의한 $a-a m y l a s e$ 저해활성 변화

$\mathrm{pH}$ 변화가 지충이 에탄올 추출물의 a-amylase 저해활성에 미치는 영향을 확인하였다. 그 결과 (Table 3), $\mathrm{pH} 4$ 와 6에서는 무처리구와 유의적인 차이를 보이지 않는 안정된 저해활성을 보였으나 $\mathrm{pH} \mathrm{2,8}$ 및 10 에서는 유의적으로 낮은 활성을 보였다. 특히 $\mathrm{pH} 10$ 의 강알칼리 영역에서 가장 낮은 활성을 나타내었 다. 이를 통해 지충이 에탄올 추출물의 a-amylase 저해 활성이 강산성과 알칼리성에서 불안정한 것으로 나타났다. 이전의 연구에서 (Lee et al., 2010) 지충이 에탄올 추출물의 총 페놀화 합물 함량이 $\mathrm{pH} 2,8$, 및 10 에서 감소함을 보고하였다. 이를 통해 지충이 에탄올 추출물에 함유되어 있는 a-amlyase 저해 활성을 나타내는 페놀화합물이 강산이나 알칼리 조건에서 파괴되어 활성이 감소하는 것으로 사료된다. 또한 Lee 등 (2009b)이 지충이 추출물의 $\mathrm{pH}$ 처리에 의한 항균활성의 변화 를 알아본 연구에서 $\mathrm{pH}$ 2-10의 범위로 처리 시 $\mathrm{pH}$ 2-8의 범위 에서는 안정된 활성을 보였으나 $\mathrm{pH} 10$ 에서 다소 활성이 감소 함을 보고하였다. 반면, 말채나무 추출물의 a-amylase 저해활 성이 산성 영역에서 안정함을 보인 $\mathrm{Lim}$ 등(2005)의 연구와는 다른 경향을 보였다. 이러한 결과들로 미루어 $\mathrm{pH}$ 처리에 따른 생리활성의 차이는 식물의 종류, $\mathrm{pH}$ 처리 범위, 생리활성의 종류에 따라 다른 경향을 보이는 것으로 사료된다. 그러나 일반적인 식품의 $\mathrm{pH}$ 가 약산성 또는 중성임을 고려할 때, 강산 성과 알칼리 조건에서 $a$-amylase 저해활성이 감소하는 것은 지충이 추출물을 a-amylase 저해 기능성 식품의 소재로 사용 하는 데는 문제가 되지 않을 것으로 사료된다.

감마선 조사에 의한 $a$-amylase 저해활성 변화

지충이 에탄올 추출물에 3,7 및 $20 \mathrm{kGy}$ 선량으로 감마선 조사를 실시하여 a-amylase 저해활성의 변화를 알아보았다.
Table 4. Effect of $\gamma$-irradiation on a-amylase inhibitory activity of ethanol extract from Sargassum thunbergii

\begin{tabular}{ccccc}
\hline & \multicolumn{4}{c}{ Dose of irradiation (kGy) } \\
\cline { 2 - 5 } & 0 & 3 & 7 & 20 \\
\hline Inhibition rate & $71.96 \pm 2.26^{\mathrm{a} 1)}$ & $71.48 \pm 1.65^{\mathrm{a}}$ & $70.24 \pm 2.27^{\mathrm{a}}$ & $69.91 \pm 0.32^{\mathrm{a}}$
\end{tabular} (\%)

1) Different letters indicate significant differences determined by Duncan's multiple range test $(P<0.05)$.

그 결과 (Table 4), 감마선 조사한 지충이 에탄올 추출물의 a-amylase 저해활성이 비조사구와 유의적인 차이가 없는 것 으로 나타났다. 이를 통해 지충이 에탄올 추출물의 a-amylase 저해활성을 나타내는 물질은 3-20 kGy의 감마선 조사에 매우 안정한 물질일 것으로 사료된다. 감마선 조사 기술은 식품의 장기저장을 위한 새로운 기술로서 투과력이 강하여 식품 및 소재의 부패방지, 제품의 안전성 및 보존성 향상 등에 효과가 있는 것으로 보고되고 있다. 뿐만 아니라 적절한 선량의 방사 선 조사는 물리, 화학 및 관능적 특성에 영향을 크게 주지 않으면서 식품 중의 유해한 미생물을 사멸시켜 식품의 가공 공정에서도 이용범위가 점차 확대되고 있다 (Yook et al., 1998; Kim et al., 2006). 따라서 본 연구에서 지충이 에탄올 추출물이 감마선 조사에 안정함을 확인하였으므로, 감마선 조사를 거치 는 일부 식품에도 지충이 에탄올 추출물을 활용할 수 있을 것으로 사료된다.

Table 5. The yields of solvent fraction from Sargassum thunbergii ethanol extract

\begin{tabular}{cc}
\hline Solvents & Yields (\%) \\
\hline n-Hexane & 9.07 \\
Chloroform & 23.27 \\
Ethyl acetate & 3.10 \\
Butanol & 2.96 \\
Water & 20.12 \\
\hline
\end{tabular}

Table 6. a-Amylase inhibitory activity of solvent fraction from Sargassum thunbergii ethanol extract

(Inhibition rate:\%)

\begin{tabular}{|c|c|c|c|c|c|c|}
\hline & \multicolumn{5}{|c|}{ Concentration $(\mathrm{mg} / \mathrm{mL})$} & \multirow{2}{*}{$\begin{array}{c}\mathrm{IC}_{50}{ }^{1)} \\
(\mathrm{mg} / \mathrm{mL})\end{array}$} \\
\hline & $5^{1)}$ & 2.5 & 1 & 0.5 & 0.1 & \\
\hline$n$-Hexane & $\begin{array}{l}83.57 \\
\pm 1.02\end{array}$ & $\pm C$ & $\begin{array}{l}67.96 \\
\pm 0.23\end{array}$ & $\begin{array}{l}3.84 \\
2.03\end{array}$ & $\begin{array}{l}11.78 \\
\pm 0.24\end{array}$ & $\begin{array}{c}0.39 \\
\pm 0.02\end{array}$ \\
\hline Chloroform & $\begin{array}{l}89.01 \\
\pm 1.21\end{array}$ & $\begin{array}{l}87.03 \\
\pm 1.17\end{array}$ & $\begin{array}{l}83.18 \\
\pm 0.69\end{array}$ & $\begin{array}{l}73.56 \\
\pm 0.32\end{array}$ & $\begin{array}{l}23.79 \\
\pm 2.36\end{array}$ & $\begin{array}{c}0.34 \\
\pm 0.00\end{array}$ \\
\hline Ethyl acetate & $\begin{array}{l}88.28 \\
\pm 0.14\end{array}$ & $\begin{array}{l}88.01 \\
\pm 0.89\end{array}$ & $\begin{array}{l}70.59 \\
\pm 1.14\end{array}$ & $\begin{array}{l}56.12 \\
\pm 1.28\end{array}$ & $\begin{array}{l}12.44 \\
\pm 1.69\end{array}$ & $\begin{array}{r}0.45 \\
\pm 0.01\end{array}$ \\
\hline Butanol & $\begin{array}{l}85.25 \\
\pm 0.18\end{array}$ & $\begin{array}{l}82.70 \\
\pm 2.21\end{array}$ & $\begin{array}{l}72.75 \\
\pm 1.23\end{array}$ & $\begin{array}{l}54.15 \\
\pm 0.98\end{array}$ & $\begin{array}{l}14.41 \\
\pm 1.82\end{array}$ & $\begin{array}{c}0.46 \\
\pm 0.01\end{array}$ \\
\hline Water & $\begin{array}{l}16.42 \\
\pm 0.21 \\
\end{array}$ & _) & - & - & - & $={ }^{3)}$ \\
\hline Ethanol & $\begin{array}{l}69.29 \\
\pm 0.70\end{array}$ & $\begin{array}{l}58.81 \\
\pm 3.64\end{array}$ & $\begin{array}{l}34.95 \\
\pm 2.63\end{array}$ & & - & $\begin{array}{c}2.30 \\
\pm 0.17\end{array}$ \\
\hline e & $\begin{array}{l}73.87 \\
\pm 2.02\end{array}$ & $\begin{array}{r}74.88 \\
\pm 3.78\end{array}$ & $\begin{array}{l}57.01 \\
\pm 3.70\end{array}$ & $\begin{array}{l}38.48 \\
\pm 0.36\end{array}$ & $\begin{array}{r}12.85 \\
\pm 1.23\end{array}$ & $\begin{array}{c}0.88 \\
\pm 0.06\end{array}$ \\
\hline
\end{tabular}

1) $\mathrm{IC}_{50}$ value is the concentraion of sample required for $50 \%$ inhibition.

2) Less than $5 \%$ of inhibition rate.

3) Not done. 
지충이 에탄올 추출물 용매 분획의 $a$-amylase 저해 활성

지충이 에탄올 추출물의 높은 a-amylase 저해활성과 열, $\mathrm{pH}$ 및 감마선 조사에의 안정성 확인을 통해 지충이의 a -amylase 저해 기능성 식품 소재로서의 적합성을 확인하였다. 이에 지충이의 활성성분을 분리하기 위하여 지충이 에탄올 추출물을 $n$-hexane, chloroform, ethyl acetate, butanol 및 water 의 극성차를 이용하여 순차적으로 분획물을 얻었다. 분획물의 수율은 에탄올 추출물에 대하여 환산하여 나타낸 것으로 chloroform 분획물이 $23.27 \%$ 의 값을 보여 가장 높은 수율을 나타내었으며, water $n$-hexane, ethyl acetate, butanol 순으로 높은 수율을 보였다 (Table 5). 지충이 용매별 분획물의 a -amylase 저해활성을 $5,2.5,1,0.5$ 및 $0.1 \mathrm{mg} / \mathrm{mL}$ 농도로 측정하 였다. 그 결과 (Table 6), water 획분을 제외한 모든 분획물에서 에탄올 조추출물에 비해 높은 a-amylase 저해활성을 보였다. 특히, $n$-hexane과 chloroform 분획물의 $\mathrm{IC}_{50}$ 값이 각각 0.39 와 $0.34 \mathrm{mg} / \mathrm{mL}$ 의 값을 보여 $0.88 \mathrm{mg} / \mathrm{mL}$ 의 값을 나타낸 positive control인 acarbose보다도 낮은 $\mathrm{IC}_{50}$ 값을 나타내어 뛰어난 a -amylase 저해활성을 가진 것을 확인할 수 있었다. 이러한 결과는 감태 분획물에서 $a$-amylase에 높은 저해활성을 보인 ethyl acetate 분획물의 $\mathrm{IC}_{50}$ 값이 $345 \mathrm{\mu g} / \mathrm{mL}$ 의 값을 보인 Lee 등 (2009a)의 결과와 유사하였다. 또한 Choi 등 (2008a)의 번행초 추출물의 a-amylase 저해활성이 $n$-hexane과 dichloromethane 분획물에서 메탄올 조추출물에 비해 높은 저해활성을 보인 것과 유사한 결과를 나타내었다. 지충이 추출물의 a-amylase 저해활성이 $n$-hexane과 chloroform에서 높은 활성을 보이는 것으로 미루어보아 지충이에 들어있는 비극성 물질이 a -amylase 저해에 효과를 가지는 것으로 사료된다. 따라서 추후 $n$-hexane과 chloroform 분획물에 대한 a-amylase 저해 물질의 분리 및 정제에 대한 연구가 필요할 것으로 판단된다. 또한 정제된 a-amylase 저해 물질의 inhibition type을 밝히는 실험 도 추가되어야 할 것으로 사료된다.

$$
\text { 사 사 }
$$

본 연구는 지식경제부의 2009년도 지역산업기술개발사업 의 지원에 의해 이루어진 것으로 이에 감사드립니다.

\section{참고문헌}

Ali H, Houghton PJ and Soumyanath A. 2006. a-Amylase inhibitory activity of some Malaysian plants used to treat diabetes; with particular reference to Phyllanthus amarus. J Ethnopharmacol 107, 449-455.

Baht M, Zinjarde SS, Bhargava SY, Kumar AR and Joshi BN. 2008. Antidiabetic Indian plats : a good source of potent amylase inhibitors. eCAM, 1-6.

Bitou N, Ninomiya M, Tsujita T and Okuda H. 1999. Screening of lipase inhibitors from marine algae. Lipids 34, 441-445.
Cho SH, Park SY and Choi SW. 2008. Effects of Eisenia bicyclis extracts and pill on blood glucose and lipid profile in streptozotocin-induced diabetic mice. Korean J Nutr 41, 493-501.

Choi HJ. Kang JS, Choi YW, Jeong YK and Joo WH. 2008a. Inhibitory activity on the diabetes related enzymes of Tetragonia tetragonoides. Korean J Biotechnol Bioeng 23, 419-424.

Choi HJ, Jeong YK, Kang DO and Joo WH. 2008b. Inhibitory effects of four solvent fractions of Alnus firma on a-amylase and a-glucosidase. J Life Sci 18, 1005-1010.

Choi SY, Kim SY, Hur JM, Choi HG and Sung NJ. 2006a. Antioxidant activity of solvent extracts from Sargassum thunbergii. J Korean Soc Food Sci Nutr 35, 139-144.

Choi Y, Lee SM, Chun J, Lee HB and Lee J. 2006 b. Influence of heat treatment on the antioxidant activities and polyphenolic compounds of shiitake (Lentinus edodes) mushroom. Food Chem 99, 381387.

Chrzaszcz T and Janicki J. 1933. "Sisto-amylase", a natural inhibitor of amylase. Chem Abstr 27, 3491-3505.

Gao H and Kawabata J. 2005. a-Glucosidase inhibition of 6-hydroxyflavone s. Part 3: synthesis and evaluation of 2,3,4-trihydroxybenzoyl-containing flavonoid analogs and 6-aminoflavones as a-glucosidase inhibitors. Bioorg Med Chem 13, 1661-1671.

Granum PE. 1978. Purification and characterization of an amylase inhibitor from rye (Secale cerale) flour. J Food Biochem 2, 103-120.

Ha JK, Emerick RJ and Embry LB. 1985. Effect of buffers and alfalfa hay on ruminal and systemic parameters of sheep fed high concentrate diets. Kor J Anim Sci 27, 80-96.

Hara Y and Honda M. 1990. The inhibition of a-amylase by tea polyphenols. Agric Biol Chem 54, 1939-1945.

Heo SJ, Hwang JY, Choi JI, Han JS, Kim HJ and Jeon YJ. 2009. Diphlorethohydroxy carmalol isolated from Ishige okamurae, a brown algae, a potent a-glucosidase and a-amylase inhibitor, alleviates postprandial hyperglycemia in diabetic mice. Eur $\mathrm{J}$ Pharmacol 615, 252-256.

Iwai K. 2008. Antidiabetic and antioxidant effects of polyphenols in brown alga Ecklonia stolonifera in genetically diabetic KK-Ay mice. Plant Foods Hum Nutr 63, 163-169.

Kageyama S, Nakamichi N, Sekino H and Nakano S. 1997. 
Comparison of the effects of acarbose and voglibose in healthy subjects. Clin Ther 19, 720-729.

Kang HJ, Jo C, Kim DJ, Seo JS and Byun MW. 2003. Physiological activities of citrus peel extracts by different extraction methods and gamma irradiation. Korean J Food Preserv 10, 388-393.

Kim MS, Ahn SM, Jung IC, Kwon GS and Shon HY. 2010. Screening of a-amylase and a-glucosidase inhibitor from Nepalese plant extracts. Kor J Microbiol Biotechnol 2, 183-189.

Kim HJ, Jo C, Kim TH, Kim DS, Park MY and Byun MW. 2006. Biological evaluation of the methanolic extract of Eriobotrya japonica and its irradiation effect. Korean J Food Sci Technol 38, 684-690.

Kim HY. 1997. In vitro inhibitory activity on rat intestinal mucosa a-glucosidase by rice hull extract. Korean $\mathrm{J}$ Food Sci Technol 29, 601-608.

Kim JH, Kim MU and Cho YJ. 2007. Isolation and identification of inhibitory compound from Crataegi fructus on a-amylase and a-glucosidase. J Korean Soc Appl Biol Chem 50, 204-209.

Kim KH, Roh SG, Li CR, Jin CF, Kim A and Choi WC. 2008. Anti-diabetic effects of banaba leaf extracts (Lagerstroemia speciosa Pers.) through solvents. JLS 18, 1305-1311.

Lim CS, Li CY, Kim YM, Lee WY and Rhee HI. 2005. The inhibitory effect of Cornus walteri extract against a-amylase. J Korean Soc Appl Biol Chem 48, 103-108.

Lee BB, Park SR, Han CS, Han DY, Park EJ, Park HR and Lee SC. 2008. Antioxidant activity and inhibitory activity against a-amylase and a-glucosidase of Viola mandshurica extracts. J Korean Soc Food Sci Nutr 37, 405-409.

Lee SH, Li Y, Karadeniz F, Kim MM and Kim SK. 2009a. a-Glucosidase and a-amylase inhibitory activities of phloroglucinal derivatives from edible marine brown alga, Ecklonia cava. J Sci Food Agric 89, 1552-1558.

Lee SJ, Song EJ, Lee SY, Kim KBWR, Yoon SY, Lee CJ, Jung JY, Park NB, Kwak JH, Par JG, Kim JH, Choi JI, Lee JW, Byun MW and Ahn DH. 2010. Effects of gamma irradiation on antioxidant, antimicrobial activities and physical characteristics of Sargassum thunbergii extract. Korean J Fooc Sci Technol 42, 431-437.

Lee SY, Song EJ, Kim KBWR, Yoon SY, Kim SJ, Lee
SJ, Hong YK, Lim SM and Ahn DH. 2009b. Antimicrobial activity of ethanol extract from Sargassum thunbergii. J Korean Soc Food Sci Nutr 38, 502-508.

Mahmud T, Tornus I, Egelkrout E, Wolf E, Uy C, Floss HG and Lee SS. 1999. Biosynthetic studies on the a-glucosidase inhibitor acarbose in Actinoplanes sp.; 2-epi-5-epi-valiolone is the direct precursor of the valienamine moiety. J American Chem Soc 121, 6973-6983.

Moon JS, Bae YI and Shim KH. 1998. The physicochemical properties of a-amylase inhibitors from black bean and naked barley in Korea. J Korean Soc Food Sci Nutr 37, 367-375.

Mulimani VH and Rudrappa G. 1994. Effect of heat treatment and germination on alpha amylase inhibitor activity in chick peas (Cicer arietinum L.). Plant Food Human Nutr 46, 133-137.

McLaughlin CL, Thompson A, Greenwood K, Sherington $\mathrm{J}$ and Bruce C. 2009. Effect of acarbose on acute acidosis. J Dairy Sci 92, 2758-2766.

Puls W and Neup U. 1973. Influence of a-amylase inhibitor (BAY D7791) on blood-glucose, seruminsulin and NEFA in starch loading test in rats, dogs and man. Diabetologia 9, 97-101.

Ryu BH, Kim DS, Cho K and Sin DB. 1989. Antitumor activity of seaweeds agar on Sarcoma-180. Korean J Food Sci Technol 21, 595-600.

Swain T, Hillis WE. 1959. The phenolic constituents of Prunus domestica. I-The quantitative analysis of phenolic constituents. J. Sci. Food Agric., 10, 63-68.

Yang F, Wang $\mathrm{L}$ and $\mathrm{Hu}$ Q. 2005. Preparation of polysaccharide derived from Sargassum thunbergii and its antioxidant activity. Food Sci 26, 224-227.

Yook HS, Cha BS, Jo SK and Byun MW. 1998. Effects of gamma irradiation on microbial decontamination, extraction yields and physiological effectiveness of Korean medicinal plants. Korean J Food Sci Technol 30, 581-589.

2010년 10월 19일 접수

2010년 11월 15일 수정

2010년 12월 3일 수리 